Braun, A. (2015) The politics of teaching as an occupation in the political borderlands - the interplay of gender, class and professional status in a biographical study of trainee teachers in England. Journal of Education Policy, Vol. 30(2), pp.285-274.

\title{
The politics of teaching as an occupation in the professional borderlands - the interplay of gender, class and professional status in a biographical study of trainee teachers in England
}

Annette Braun, Institute of Education, University of London

Contact: a.braun@ioe.ac.uk

Abstract

A lack of esteem for teachers and the teaching profession is a central tenet underpinning policy reforms put forward by the 2010 UK Government White Paper 'The Importance of Teaching'. This article argues that the policy problem and solutions presented in the White Paper lack awareness of the historical and social positioning of teaching. Drawing on in-depth interviews with 32 Londonbased secondary teacher training students from various social class and ethnic backgrounds, this paper asks how the profession is perceived and what sort of choice it is for the trainees. It employs a Bourdieusian lens and concepts of social and cultural capital to examine the interplay of gendered, classed and 'raced' biographies in relation to individuals' decisions to become teachers. Understanding the social world as 'accumulated history', as Bourdieu does, stresses that experiences and outcomes are rooted and collected in a series of historical structures and functionings. The paper argues that the ambiguous status of the profession is both a function and an effect of its conceptualisation as feminised. It also asks whether the weak professional standing of teaching has further destabilising consequences in the present political moment where a string of neoliberal and neoconservative policy reforms reshape the profession.

Keywords: teaching profession, policy reform, biographies, gender 
'There is no calling more noble, no profession more vital and no service more important than teaching' Michael Gove, DfE Schools White Paper 2010

One of the recurring themes of the 2010 School White Paper 'The Importance of Teaching' (DfE 2010), which put forward a series of steps towards system-wide educational reform in England and which featured the above quote by the then education secretary Michael Gove, is a lack of esteem for the profession. The problem of esteem is not new, Amitai Etzioni infamously described teaching as a semi- rather than a 'full' profession in 1969 (Etzioni 1969) and British media reports frequently criticise the calibre of teaching graduates and depict the numerical dominance of women and teacher recruitment in general as a problem (e.g. Skelton \& Francis 2009, Observer 2013, Adams 2013). Policy itself has also often been adversarial towards teachers, as Maguire and Dillon argue: 'ever since the state took over the responsibility for supplying teachers for schools in the nineteenth century, teachers and their work have been almost constantly subjected to criticism and reforms' (2007, 85). The reforms being proposed by the 2010 White Paper with regards to improving the reputation of the profession centre on aiming to recruit more 'top' graduates into teaching. This takes the form of supporting and extending the Teach First programme (TeachFirst 2013) which recruits mainly from Russell Group Universities ${ }^{1}$, offering financial incentives for graduates with $1^{\text {st }}$ and 2:1 degrees in shortage subjects and cutting funding for training graduates with a degree below 2:2. These attempts at demand-side control arguably ignore key supply-side aspects regarding recruitment into Initial Teacher Education (ITE). Importantly, it is a set of policy solutions devoid of awareness of the historical and social positioning of teaching in England where some of the answers regarding the esteem in which the profession is held might be found. This paper addresses these dimensions by giving a brief historical account of teaching as a career option and by examining what

\footnotetext{
${ }^{1}$ A group of 24 research-intensive universities which are commonly regarded as the UK's leading universities and which have comparatively high entry requirements for students.
} 
sort of choice it is from the perspective of student teachers themselves. In particular, it is going to address the sometimes overt but often unspoken gender dimensions linked to the esteem of the profession.

This paper uses data from in-depth interviews with 32 London-based secondary teacher training students from various social class and ethnic backgrounds to explore the interplay of their gendered, classed and 'raced' biographies when deciding to go into teaching. Using biographical narratives as a starting point, it asks whether the ambiguous status of the profession is evident in student teachers' own accounts and examines whether this is a function or an effect of its conceptualisation as feminised. Finally, the paper poses the question whether in the present political moment, characterised by a string of neoliberal and neoconservative reforms such as extending individual schools' autonomy and flexibility over teachers' pay and a shift from university-led to school-based training (DfE 2010), the comparatively weak professional standing of teaching has further destabilising consequences for the profession. It raises questions about how individualising policy interventions such as TeachFirst, which are becoming widespread in other country contexts outside of England (e.g. TeachFirst Germany www.teachfirst.de), relate to the historical and gendered position of teaching.

\section{Teaching in historical perspective - shifting and continuing dimensions of gender and social} class

When considering historical trends in teaching as a career choice, gender emerges early on as a key variable. As the public education system expanded in the $19^{\text {th }}$ century in the wake of a new industrial age, a growing number of women were recruited, particularly as teachers for young children (Bradley 1989, Miller 1992). Industrialisation brought with it increasingly complex social 
structures and, in order to equip children for adulthood, it became necessary to teach them 'the forms of behaviour, knowledge and skills which will be necessary in their various future social roles' (Bradley 1989, 204). Schooling for the masses became a prerequisite for an effective industrial workforce and teaching became inseparable from socialisation. Bradley (1989) and Dillabough (1999) argue that to teach young children became to be seen as a 'natural' extension of women's mothering roles. Although the work required teachers to impart basic reading, writing and numerical skills to their pupils, it was very much perceived as calling for little in terms of intellect or skill, apart from women's 'innate' capacities to care and to be 'good' with young children (Bradley 1989, Miller 1992). Importantly, women teachers were less of a drain on the public purse as they could be employed much more cheaply than male teachers. In England, up to World War I, fully-qualified women teachers' salaries were about three-quarters that of men's (Oram 1989). However, women also made up the majority of uncertificated teachers who would only receive around half the salary of fully-trained teachers (Bradley 1989). Furthermore, almost all supplementary teachers, the lowest and most poorly paid grade of all, were women (in 1907, out of 18,632 supplementary teachers, only 195 were men) (Bradley 1989, 207). Historical evidence like this links to Preston's assertion that 'jobs became female jobs as women were hired for them [and] a teaching job acquired a woman's wage, as women were hired' (Preston 1995, 398) and serve as an important reminder that gendered job characteristics develop over time until they are accepted as the natural order of things.

By 1870 , the number of female teachers in the state-aided sector was already greater than the number of male teachers and the following decades saw a dramatic further feminisation in terms of numbers: by 1913,75 per cent of teachers in schools aided by state grants were women, a figure that remained more or less unchanged until World War II (Bradley 1989, 206). In fact, the figures are very similar today, in 2012, 73.3 per cent of regular full and part-time teachers in England were female (DfE 
2013a). Historically, during the period from the late eighteen hundreds onwards, teaching was one of the few 'respectable' career alternatives open to lower middle class and some working class girls (nursing was another), whilst a general rise in working class wages made teaching a less attractive option for working class boys (Bradley 1989, Miller 1992). The class status of teaching in England has thus always been interlinked with gendered dynamics and it was women in general and men from working class backgrounds for whom teaching presented a 'good' choice and room for social mobility. In the early days of state schooling, practically every certified teacher could expect to become a headteacher. ${ }^{2}$ Yet, the expansion of the school system, the growing size of schools, and the development of departmental structures meant that women became increasingly less likely to reach higher posts (Bradley 1989, Preston 1995). The professionalisation of teaching in the form of standardised training and inspection regimes further exacerbated the development of a sexsegregated, hierarchical system of control and supervision, with the suggestion that women could be school inspectors raising heated debates, including among women teachers (Bradley 1989, 208). These developments, Preston argues, allowed education reformers to 'achieve their goal of making schooling a more influential social institution without granting power to the growing number of female teachers' $(1995,392)$. In this way and in contrast to other professions such as law and medicine, teachers themselves never managed to gain comprehensive control over the establishment and destiny of their profession (Willis 2005, Hargreaves 2006).

A new type of female entrant to the profession emerged in the early $20^{\text {th }}$ century with the influx of women from higher middle class backgrounds into teaching. Wider societal changes and shifts in the social class system in England led to the disappearance of governess' posts, which resulted in many women from more 'genteel' backgrounds turning to state school teaching (Bradley 1989). The latter offered comparatively better pay and also greater independence than the privately arranged

\footnotetext{
${ }^{2}$ Many small schools only had one certified teacher and perhaps one or more assistants.
} 
governess positions. Furthermore, the rising number of girls' secondary schools and the opening of higher education to women created new possibilities for high-level teaching opportunities (Bradley 1989). It was then that the trend for a considerable proportion of female college and university graduates to become teachers became established, a trajectory that could be observed until well into the second half of the $20^{\text {th }}$ century (Dale \& Egerton 1997). Parallel developments were in evidence in the United States where Clifford noted that while 'the daughters of farmers and small businessmen were the majority of the nation's teachers' $(1987,5)$ women graduates from elite colleges also overwhelmingly became school teachers if they entered employment. Thus early on, teaching transpired as a space where people, and in particularly women, could find a place of their own and where social class boundaries crossed. The presence of these higher middle class women is significant in terms of the way in which the profession was perceived and whilst teaching was a career that was seen as a moral vocation for which, for example, little financial reward was expected, this view started to be challenged by these women who were concerned with the status of teaching and demanded better professional recognition, treatment and remuneration. According to Bradley, 'the determination of these women helped to prevent teaching, as a female-dominated profession, from sinking to the level of nursing' in terms of lack of recognition and deference to professional expertise (Bradley, 1989, 209). Throughout the $20^{\text {th }}$ century, the struggle for professional recognition of teaching was fought on two fronts. In the arena of teacher training, by introducing and emphasising academic and pedagogical theory and by establishing teaching as a graduate profession (Ward and Eden 2009) and in attempts to manifest it as a self-regulated profession, for example through the introduction of the General Teaching Council for England in 1998 (Willis 2005). The teaching council has since been abolished (in 2012) and the 2010 White Paper is extending provision for school-based instead of university-led training of teachers (DfE 2010), privileging practical experience over some aspects of pedagogy and theory. So the fight for professional status continues and the policy environment of teaching, always uneasily balanced 
between the state and the ideal of the self-determined profession (Lawn 1996), has reversed into a realm where teaching once again could be considered a 'directed profession' (Bottery \& Wright 2000) led by the changing demands and ideologies of consecutive governments (Maguire \& Dillon 2007). This dependent position of the profession suggests that teaching is ill equipped to register effective dissent to the neoliberal reforms which dominate current education policy (Ball 2013).

So teaching has always occupied a contested and ambiguous place in policy and professional hierarchies and in this paper, my interest lies with the perspective from the inside, from those choosing teaching as a career and the choice this presents for them. Purcell and Wilton (2005) used data from a national representative sample of UK graduates to compare characteristics of those who have gone into teaching with those who have chosen other careers. Those with a teaching qualification were more likely to be female, have studied as mature students, attended a post-1992 university and have gone to state schools than graduate overall. In addition, those who studied for an undergraduate degree in teaching had lower average attainment in pre-higher education qualifications and were more likely to have come from lower socio-economic backgrounds although, these differences were not found among graduates who went into teaching via a postgraduate route. The notion of 'choice' in relation to education and occupational decisions has of course received considerable critique by a range of authors (e.g. Ball et al., 2000; Reay et al., 2005; Tomlinson, 2013) who emphasise that in particular social class, gender and race inflect in a variety of ways on individual decision-making in relation to occupation and career choices and outcomes. The teaching workforce figures with their high ratios of women teachers (DfE 2013a), for example, point to teaching as an undoubtedly gendered field and so not the 'neutral' career choice that the gender blindness of a policy document such as the 'Importance of Teaching' White Paper (DfE 2010) implies. It is also, as Devine (2005) who studied teachers and doctors observed, fairly 'open' to men and women from working class origins. Teaching can present a route to upward social 
mobility for some teachers from ethnic minority backgrounds (Menter 2010), although whether teaching is considered a desirable career choice by both families and students from minority ethnic backgrounds has been questioned by a number of research studies (e.g. Gordon 1994, Su 1997, Maylor 2009).

\section{The study and its theoretical framing}

The study on which this paper draws formed part of a research project on the gendered biographical pathways of entrants to the teaching profession (Braun 2009). I interviewed 32 PGCE (Postgraduate Certificate of Education) students, all training to become secondary teachers. The interviews were conducted in the spring and summer terms of 2005 and 2006 and interviewees were drawn from four different teacher training institutions across Greater London. Interviews lasted between one and three hours, with most taking around two hours. All the interviews were recorded and fully transcribed. I visited the four training institutions and invited PGCE students to take part in the research by providing me with their contact details. As more students volunteered than could be included in the study, in selecting interviewees I tried to cover a mix of subject areas, women and men, students from different ethnic backgrounds and ages. 23 of the 32 interviewees were women, nine were men. Students were studying to become teachers in a range of subjects: mathematics (8), social sciences (8), English (6), science (5), design and technology (3) and music (2). Teaching was the first career for 18 of the interviewees (aged 22-25), for the other 14, teaching was to be their second or even third career (these interviewees were aged between 26 and 38). The majority of the study participants came from White British ethnic backgrounds (22), six were British Asian, two were Black African and two were from South-East Asian backgrounds. The majority of interviewees 
in this study (20 out of 32) came from families where either their mother or father ${ }^{3}$ worked in occupations classified as social class one or two (managerial or professional, see Table 1 below) traditionally seen as middle class on standard socio-economic indicators (ONS 2010). A further five interviewees are categorised as 'intermediate' (class 3), whilst the other seven have parents in classes four to seven which are conceptualised as working class.

\section{[insert Table 1 here]}

Such broad classifications necessarily simplify and for the purpose of this analysis, I also chose not to categorise second-career teachers according to their own previous occupations, but to refer back to their parents as I am interested in what might be termed 'childhood habitus' (Bourdieu 1977). The socio-economic classification of school teaching is class two, lower professional and managerial (ONS, 2010), and also in everyday contexts, teaching is broadly seen as a middle class occupation, albeit at the 'lower' end (Hargreaves et al., 2007). Even this rough grouping of interviewees already suggests that there are a number of people in the sample for whom going into teaching represents an outward move into the middle classes and a move 'up'. Whilst for the 20 interviewees with class 1 and 2 backgrounds, keeping in mind that this is a very crude grouping, the question arises whether the lower middle class status of teaching presents a problem.

The biographical pathways of the interviewed trainee teachers were examined through a theoretical lens informed by Bourdieu and concepts of social and cultural capital, together with his notion of habitus (Bourdieu 1997). Understanding the social world as 'accumulated history', as Bourdieu suggested, emphasises that experiences and outcomes are not randomly generated, but are rooted and collected in a series of historical structures and functionings. Families play a key role in ensuring the tenacity of habitus in that parents impart and model 'things to do or not to do, things to say or not to

\footnotetext{
3 This is a fairly unorthodox way of handling socio-economic class classifications which traditionally rely on social class being determined in relation to men, i.e. fathers and husbands.
} 
say, in relation to a probable "upcoming" future' (Bourdieu cited in Ball, 2003, 16). In addition to families, friends and the wider community also influence education and occupation pathways and reinforce patterns of achievement (Devine 2004). By setting biographical characteristics alongside accounts of education and career decisions, Bourdieu's concepts can help in identifying common outcomes and trajectories.

\section{Deciding to go into teaching: class, transitions and the status of teaching}

\section{Reconciling working classness}

In the historical account above, I observed that teaching is an occupation that allowed for some class transitions in the past, often linked to the gendered aspects of the profession. Current teacher recruitment policy with its emphasis on 'top' graduates (DfE 2010) does not show much awareness of teaching as a place for social mobility, but in my study, Anjali, Matthew and Megan, all from working class family backgrounds, were very aware that they transgressed class borders by joining their new profession.

I am now middle class because I'm a teacher. But I've come, I've come from a working class background, I'm very much in touch that I've come from a working class background, I see it as a positive thing and I've moved my way up. [] [T]hat's what my parents wanted, us to move away, and they wanted us to go to university, get a degree and move up the scale, definitely. (Anjali)

Anjali, whose parents came from India, grew up in a seaside town where her family ran a small business. On her parents' wishes she went to a high-performing single sex secondary school where she was one of very few ethnic minority students. She links her education trajectory to wider discourses of migration and education, echoing research that often stresses parental investment into 
education by immigrant families (e.g. Glick and White, 2004). Matthew, on the other hand, was acutely aware of the differences between his own family and the middle class environment in which his girlfriend, who also trained to become a teacher, had been brought up. In fact, he thinks it was her influence that made him think about teaching in the first place:

[I]t was actually my partner who [read about a Student Associate Scheme that places university students in schools] and she said you might want to have a look at this, you might be interested in it. I hadn't really explored the possibilities, I wasn't really into reading all the emails university sent me. [] So, possibly if I hadn’t have known her, I would have taken a different route. Which is perhaps interesting as well, because she is a, she is from, she is quite, a very middle class sort of individual, so. (Matthew)

The middle class environment of university, which all the interviewees have experienced, can - as Matthew speculates - open up new perspectives and directions. In his example, it is a personal connection that transforms options (an email from the university about the Student Associate Scheme) into reality (joining the scheme and eventually applying for a place on a PGCE course). Other studies also suggest that education biographies, especially those of students from 'nontraditional' backgrounds such as working class, ethnic minority or mature students, are often shaped by serendipity and choices made on intuition and affective responses, rather than rational planning (Reay 2001, Reay et al. 2005). Matthew muses that his parents' value systems, which he describes as 'pretty working class', mean that they can no longer really understand what he is doing professionally:

My dad is a retired driving instructor and my mum is a bookkeeper, which I suppose are kind of quasi-middle class professions now, but they do have, I would say they have pretty working class value systems. They certainly show those values towards my occupation now, 
they don't really understand it. [] And they're kind of, I was on the phone to my dad the other day, saying 'I just done a parent's evening'. He was like 'What, you!?' [laughs] (Matthew)

Similarly for Megan a gulf is opening up between herself and her long-term boyfriend. Megan, whose mother is a hairdresser and whose father works as a railway mechanic, met her boyfriend in secondary school. While she went on to an FE college for A-levels, a gap year in Africa where she taught English and a development studies degree, she says that her 'partner is, in terms of qualifications he doesn't have anything in comparison, he hasn't been to university, stopped at his, I don't know, BTEC at college'. She emphasises on numerous occasions how supportive and proud her boyfriend was of her education achievements and qualifications and how his more 'carefree' attitude helped her relax when she was stressed about work. At the same time, she experienced frustration with their diverging lifestyles and knew that there were worries - at least from his side that this opening class divide may drive them apart:

I do find it frustrating in some ways, because I'd be like, for example yesterday, it's a lovely sunny afternoon and his parents have invited me round to have lunch in the garden or whatever, cause his aunt has just come over from Jamaica, and I'm just like, I've got to get home, I've got to sort myself out [and prepare for school]. (Megan)

I'd say, my partner is working class and his family are very working class, so in terms of my friendships in terms of that area, are very working class. And there is quite a big divide in that as well, because he finds it really difficult to mix with my [gap year and university] friends. [] We've had kind of arguments, and he thinks I'm going to run off with an amazingly rich, educated man or something. (Megan)

Megan's familiarity with and movement through differently classed social fields (Bourdieu, 1977) the working class environments of her own and her partner's family; friendships with fellow, more 
middle class, gap-year students; and the university experience - means she can navigate through these different worlds (Devine \& Savage, 2005). But she is also aware of the differences and rifts between them and the accompanying negative aspects: her boyfriend and her having clashing daily routines, arguments and jealousies related to the different circles in which they socialise. Reay describes this as an 'emotional tightrope', where 'the choice to both move away and become different to the natal family can evoke powerful feelings of anxiety, loss, guilt and fear alongside the more accepted emotional responses of hopeful anticipation, excitement and pride' $(2005,921)$.

Becoming a teacher is a process of transition for Anjali, Matthew and Megan, stepping into a newly classed area but with the familiarity teaching provides as an occupation known from one's own schooling and with clearly defined entry routes (Britzman 1991). Here we can see a manifestation of teaching as occupying a 'borderland' position, a middle class profession with a fair number of working class recruits. Matthew also conceptualised the middle class world of education as more 'female' and contrasted this with his experience of the more 'masculine' world of his working class family and old friends. It could be argued that these multi-layered classed and gendered dynamics within the profession are both an expression of and further facilitate class permeability (Menter 2010). Policy schemes such as Teach First on the other hand have been identified as reproducing middle class advantage and access to privileged cultural and social capital for its mostly middle class participants (Smart et al. 2009). By promoting an elite graduate scheme such as Teach First as the foremost vehicle to boost teacher recruitment and esteem (DfE 2010), the UK government arguably ignores a major part of the historical and current social class context of teaching as a terrain where working class recruits have always been invaluable (Maguire 2001). 


\section{Having teachers as parents}

Amongst the interviewees there was a substantial subset who had a least one parent who worked or used to work as a teacher or in an education capacity (12 out of 32$)^{4}$. Interviewees with teacher parents (and some others) often described a form of socialisation into the school environment from an early age which helped in identifying whether this might be a type of work they would like. Holly has been helping her father, a primary teacher, when he took his pupils on outings and with various Christmas, choir and other events since she was a GCSE student and 'did really enjoy it'. Caitlin, Kate and Phoebe had in Phoebe's words been 'roped in' by their primary and nursery teacher sisters and mothers for similar tasks. This sort of helping out, not just in schools, but also in other community settings such as youth clubs or choirs whilst still being a teenager, had distinctly gendered dimensions. With one exception, it was only reported by women in the sample. Commonly these activities were led by their parents, teachers or other relatives and it was the adults who asked the girls whether they were interested in helping out. Jagdish was the only male interviewee who described getting involved in this kind of activity. In his case, he asked his maths A-level teacher whether he could help tutor some younger pupils as he was thinking of becoming a teacher himself. So with the exception of Jagdish, this mode of being socially involved, trusted and engaged in a task as an educator was more likely to have been part of girls' experiences growing up. We know that girls and boys have very different day-to-day experiences growing up, even if their childhood habitus in terms of family background, is similar (Walkerdine et al., 2001). However, that expectations and opportunities to be socially engaged are focused on girls rather than boys (Paechter 2007) should give us pause to think. If person-centred professions such as teaching are to become more gender-balanced, society as well as education policy needs to address and redress gendered expectations of children and young people.

\footnotetext{
${ }^{4}$ Ten had teachers as parents and two interviewees had mothers who worked as classroom/learning support assistants.
} 
Not every parent who knew teaching from the inside was delighted that their child had decided to go into teaching. Both Holly's father and Emily's parents counselled their daughters against it:

I do remember telling my dad, and my dad was so disappointed. [laughs] [] His concern was the politics of teaching, he is a union rep, you know, aging hippy best describes my dad. $\mathrm{He}$ just, so his concern was, 'Are you sure you want to get into all this planning, and paperwork and politics?' [] My reaction was very much, 'Well you do it [laughs], can't be that bad!' And he's ... his reaction is always, 'Yeah, but I get away without doing quite a lot of it, I'm ... nobody can mess with me.’ (Holly)

They said don't do it. [] It's too much work, too hard work, takes over your life, so they said don't do it, do something else, do something easier, do something with more money, you know, something else. They would have liked me to have done a $\mathrm{PhD}$, because they're academic you know, they like the idea of research and things. (Emily)

The disappointment expressed by Holly and Emily's parents as relayed by their daughters in the extracts above is qualitatively different. Holly's father takes issue with a school system that in his eyes is getting increasingly bureaucratic and managerial and he does not want Holly to be ground down by it. He sees himself as someone who can resist or ignore many of these demands of performativity (Ball 2003) and asserts what Sachs (2001) has identified as an 'activist teacher identity'. However, he can not see his daughter or any incoming new teacher to be able to do the same. Holly believes that his concern is not so much with her going into teaching, but with anyone going into teaching. Emily interprets her parents' reaction differently. Whilst they also express concern about the nature of the work, she believes that her parents might be disappointed with her for 
not going to do further postgraduate research ${ }^{5}$, for not doing 'something else'. Both these accounts are of course relayed and filtered through their daughters, however, these interview extracts hint at a certain ambivalence with the position and status of teaching, particularly from a teacher and also a middle class perspective.

\section{Ensuring middle classness}

The specific dynamics of this ambivalence become clearer when considering the accounts of middle class interviewees whose parents did not work in education. The examples of Iris and Jamie below show that deciding on the PGCE course was a step they felt they had to assert against the expectations of their parents. Iris's father was an accountant with a successful private sector career. Having come as a southern European migrant to Britain as a young man, he managed to advance through the class system through work and study and took pride in having been able to sent his two daughters to private school. School teaching was not what he had envisaged for them:

When I sort of was in my first year A-levels [I was considering teaching]. But my dad is, is kind [laughs] I can't really, well, I sort of think that he was a bid of a snob at the time because he didn't really want me to go into teaching. He wanted me to sort of do, sort of do, 'You know you shouldn't be teaching, you can do so much better, you could do so much more. [] I've given you a really good education, you should really use it to go and, you know'. Basically in his eyes, it was go and make lots of money []. Go and work in the City. (Iris)

Teacher training was lacking prestige in money and status terms for Iris's father. He felt she could 'do so much better' and that he was not making good use of the expensive private education he had provided her with. By the time Iris was 24 , however, she had been working in diverse private sector jobs which in her words were 'going nowhere' and in which she was repeatedly faced with the

\footnotetext{
${ }^{5}$ She was due to start a PhD, but funding problems let her to pursue a PGCE instead.
} 
prospect of potential unemployment. At this point she decided that she would, after all, give teaching a try. Thus she presented her decision to her father as looking for a job that was 'secure', with a laid out career path, where she will also be able to combine motherhood with a professional job:

I thought right, if I get this interview [for the PGCE course], once I find out I'm going to tell them properly, so I was psyching myself up to that. And I kept making all these drives at like saying, you know, 'Oh, well, the private sector is so unpredictable, you always just keep being made redundant. I'm 24 now, and I've got no proper career, you know, I studied and I'm going nowhere'. [] [A]t least when I've got my family, at least the holidays are going to correlate with what they've got as well. It's really good for like, I can still have my career, but I can still be there for my children as well. (Iris)

The realities of a competitive labour market and her wish to have children prove a weighty enough argument to change Iris's parents' perspective. It appears that in a very old-fashioned sense, teaching is still perceived as a 'good' career for a woman, or at least for a mother (Bradley 1989). Within a social and cultural context where the care of particularly young children continues to be strongly and almost exclusively linked to women, and where traditional understandings of family relationships which place mothers at the centre - whilst locating fathers on the periphery - dominate (Vincent and Ball, 2006; Braun et al. 2011), occupations considered to be 'parent-friendly' such as those in education, will continue to be understood as essentially 'women-friendly'.

Ambivalence towards teaching and its status was at the centre of Iris's account. She is defensive and defiant, repeating numerous times in the interview that she is 'proud' to be a teacher. We again see an ambiguity, with teaching being caught in a triangle of being a 'good', a 'good enough', but also a 'not that good' profession. This speaks to a number of questions around esteem and the reputation of the profession that other research has identified as well (e.g. Hoyle 2001, Cockburn and Haydn 2004, 
Hargreaves et al. 2007). Cockburn and Haydn, for example, surveyed a large sample of graduates and school leavers about their attitude towards teaching as a possible career and found considerable ambiguity on questions such as whether teachers have high status (41 per cent agreed, 58 per disagreed) and whether teachers need to be clever (67 per cent agreed, yet 33 per cent disagreed) (2004, 34-35). Hoyle (2001) suggests that it is the close and vital relationship with children, found by numerous research studies to be the most important reason for graduates choosing teaching (e.g. Johnston et al. 1999, Reid \& Thornton 2000, Hobson et al. 2004 all identified 'enjoying working with children' as the main motivation of those entering the profession), that prevents teachers and teaching from being considered high status. In a four-year UK government funded study on the status of teachers and the teaching profession Hargreaves and her colleagues found that in a largescale survey, just under half of the general public respondents considered teaching to be an attractive career (Hargreaves et al. 2007, 81). Yet, neither the general public nor the teachers and trainee teachers surveyed by the researchers thought teaching to be a particularly high status profession, giving a lack of professional autonomy, high degree of external control and regulation, and uncertain standing with regards to 'reward' and 'respect' as reasons (Hargreaves et al., 2007, 34-36). Out of a list of 12 professions, teaching was ranked fourth from the bottom, before nurses, social workers and librarians - all female-dominated occupations - and with surgeons, barristers, doctors and vets topping the list (Hargreaves et al., 2007, 36-37). So it appears that there are a number of inherent contradictions as to the 'worth' of the profession and policy developments, such as ever greater accountability and prescription of teachers' work (Menter 2010), which potentially exacerbate rather than address these contradictions. The present paper adds to the literature on this by exploring these tensions in qualitative accounts of trainee teachers and by examining them in relation to interviewees gender and social class positions. 
A sense of this uncertain professional standing is also in evidence in Jamie's account of his educational and career pathways. In contrast to Iris, Jamie describes a process of decision making and stops and starts that is not so much dominated by his parents' outright disapproval, but Jamie's sense that he has to match his father's academic and professional success:

[M]y immediate family actually they are very supportive [of me doing a PGCE], and actually I don't, although I used to feel a lot of external pressure, it was felt pressure, it wasn't actual pressure coming from my dad. I really, really felt that I had to match his academic achievements, I really did feel that! (Jamie)

Jamie's father is a professionally successful Oxbridge educated engineer from a working class background and both Jamie and his older brother have been high achieving pupils and students. Jamie started a degree in medicine, which he changed to a degree in neuroscience, at the end of which he started a science doctorate in Oxford. He stopped his $\mathrm{PhD}$ studies in the second year and described the decision as a fundamental shift to acknowledging what was important to him in his life, connecting and working with people, rather than the impersonal process of scientific enquiry. And whilst he felt that a career in medicine would have been considered by outsiders as an acceptable way of working with people, school teaching fails to have the same sort of prestige. His trajectory from prospective medical doctor, to future scientist, to teaching trainee is being read as a downward one by some family members:

I do feel some sort of pressure from more distant members of my family. [] My grandma on my dad's side, yeah, there'd be little things that she'd say to me, like, 'Oh, it's a shame you didn't complete your medical training', or 'It's a shame you didn't get your doctorate from Oxford'. And for me that does make me think she isn't really thinking about me, she is thinking about the prestige that comes with these things and how - it makes her sound terrible, and I'm sure she doesn't think consciously like this - but to other people around her, 
it's going to make her family look big and successful, to have all these accolades and prices and whatever. (Jamie)

Whether teaching commands respect and esteem is also a moot point among some of the interviewees who immigrated to Britain or whose families were migrants. Harsha and Iram below explain how teaching is lacking in status in the eyes of their extended family members and link this with its perceived poor financial rewards. Matu raised the same point and he also identified a more widespread lack of respect for teachers in England, contrasting this with his experiences in Kenya, where teachers are held in high professional regard:

Teachers don't have a high status in our family, you got to be a doctor, an accountant, a lawyer, you know. (Harsha)

I mean originally it was very much the case of 'Why are you not working in a bank?', that was very much the standard response. But I reckon now, a lot of people have just gotten used to it, extended family-wise. They just gotten used to the fact that I am a teacher, I'm happy doing it, and it hasn't caused too many problems. I have to admit when I first said that I'm going to be doing it, there was a few sort of, 'Oh, you could earn so much more money doing this'. I think very much an Asian thing is earning money, it is very much sort of a status symbol, I suppose. (Iram)

I mean doctors and teachers are the most respected people in Kenya. And probably growing up in that kind of, I mean here, people look down on teachers, I don't know, I think it's, I think this society is sort of driven by the money issue, you know. So teachers don't make a lot of money, everybody says that, it's obvious, and then everybody is judged with how much money they make. (Matu) 


\section{Teaching as a borderland profession}

The ambivalent position of teaching as a good, good enough or perhaps not so good profession, clearly depends on the individual and their circumstances (Stronach et al. 2002) rather than on their belonging to a particular (broad) social class. Yet, from these students' accounts it is clear that education and professional trajectories are put in place and facilitated by the particular social, cultural and economic capitals available to interviewees. Having firsthand experience of helping out in educational settings as a young person, for example, and being positioned by adults as being 'good' at this type of responsible and people-centred work, builds and reinforces a self-image of being just such a person. The kind of choice on offer fits Bourdieu's assertion that 'We can always say that individuals make choices, as long as we do not forget that they do not choose the principle of these choices' (Wacquant, 1989, 45). Gender as a player in 'choice-making' is both on and off the radar in interviewees' personal accounts, although it is entirely absent from policy documents such as the English Education White Paper (DfE 2010). It is an aspect of being trusted as an educator in one's teens, as well as a conscious and integral part of life planning decisions. Iris, whose self-made father would have liked her to become something 'better' than a teacher, reminds her family of the fact that as a woman who wants to have children, teaching becomes the 'better' choice. There are parallels here with Fiona Devine's research on teachers and doctors where she found that only one of the 12 British doctor families she interviewed considered teaching a possible (and by implication acceptable) career choice for their son, who was in turn described by his parents as 'not particularly academic' (2008). The doctor parents in Devine's study had 33 children between them and almost without exception wished for medical careers for them. They only considered other options if they believed their children will not obtain the necessary grades and in contrast to the lone son above, for 'non-academic' daughters, teaching was generally seen as quite a good choice by the parents. Sadly, 
labelling an occupation as female-friendly can mean that all sides lose, with men being seen as doing 'women's work' and women considered as doing 'only women's work'.

In this study, transitions as well as accommodations were made by working class and middle class interviewees in terms of their classed understandings of themselves and of the position of the profession they were about to enter. It was also evident that the cultural and social capital bestowed by having teachers as parents facilitates access and knowledge about teachers' everyday lives, but may be experienced as a mixed blessing when interviewees sense that their teacher parents would like something different and 'better' for their children. Ethnic minority interviewees in the study were grappling just as much with reconciling their own and teaching's social class position, as their white UK peers. In some cases, they also had to live up to family and community expectations of social mobility over and above those experienced by their white UK colleagues, as their professional pathways became invested in by the people around them as representative of the status and experiences of migrants to the UK more generally. Through all this, teaching emerged ever more as a borderland profession, a compromise vis-à-vis other occupation options - compromise here entailing the dual meaning of potentially being compromised (as a feminised, lower status and lower pay profession than some other graduate careers), but also holding a mutual promise, where teaching is seen as delivering a good fit with one's life circumstances, personality and imagined future. As a classic 'good enough' and fallback decision (Morrison 2012), teaching therefore has to constantly grapple with its professional standing and esteem vis-à-vis both more and less prestigious occupations.

Teaching and thus teachers are charged with a task of enormous proportions: the education of the nation's children, or what Britzman (2000) calls 'world making'. What is striking is the impossibility of this premise: the idealised expectations of what teaching should accomplish, set against the futility of what it could possibly achieve. Yet its optimism and pathos is also reminiscent 
of the somewhat hollow quote by Michael Gove at the start of this paper. In another paper related to this research project I have argued that the 'vocational habitus' of teaching meant that teaching was lent an elevated status as a 'worthwhile' and 'rewarding' profession by interviewees (Braun 2012). I suggested that this worthiness was a strategic positioning to consciously counteract potentially derogatory discourses of teaching as a semi-profession. In this alternative or counter-hegemonic moral universe, teaching outranks other, less people-centred, occupations. Counter-hegemonic value systems of course have a long-tradition in discourses of feminine spheres (e.g. Gilligan 1982, Noddings 2005), whether these are the private domain of the family, or the public arena of feminised often caring work. These framings, however, are in danger of working as reproductive rather than productive discourses. They entail all the problems and promises that such a 'standing apart' holds the promise of being valuable and essential in its own right having to stand up against the problem of a lack of recognition (and financial reward) in the context of conventional, male-oriented value systems and professional hierarchies. Moreover, it does not present a challenge to these paradigms, with the possibility of a reassessment of these essentialised value-systems retreating into the background. If teaching and other people-centred and public sector work is to gain in esteem and recognition rather than being unrealistically idealised, a fundamental mainstream shift in what is to be valued and rewarded has to take place. It is hard to see how the British government's simplistic emphasis on trying to attract 'top graduates' into teaching in England by offering leadership positions for these recruits (TeachFirst 2013) is going to be helpful in this respect as it risks creating a two-tier system of teachers and teaching (Maddern 2009), essentially putting forward a message that there are 'ordinary' teachers and then there are Teach First teachers.

In this paper, I have suggested that teaching as a profession is located in an intermediate or borderland space. It has historically been, and continues to be, a site for social and educational mobility for women and for those from working class and, more recently, ethnic minority 
backgrounds (Menter 2010). Yet, there are clear disadvantages to teaching taking up residence in the borderlands of gender, social class and professional hierarchies. As a feminised, lower middle class and lower status profession, it is unlikely to leave the borderland and enter the 'mainland' where the decisions about its professional future are made, and which present the social and policy contexts in which it has to operate (Wright 2012). Teaching is an area that is famously and notoriously exposed to constant policy churn (Braun et al. 2010). At a policy moment where a string of neoliberal and neo-conservative reforms that are potentially detrimental to teaching and teachers, such as performance-related pay (DfE 2013b) and the cutting of university-led training places (Maddern 2012), are put forward and implemented, the professional weak positioning of teaching means that the potential to successfully oppose the introduction of such polices is slim. Policy interventions such as Teach First which suggest that graduates go into teaching initially, before potentially moving on to careers in other sectors do not ameliorate, but arguable exacerbate the profession's weak standing. If teaching is only something that is useful to pursue for a couple of years as a part of a specially sponsored management programme, this does not actually speak well for the profession, even if a good proportion of Teach First graduates decide to stay on in teaching (TeachFirst 2013). A sense is being conveyed that by 'just teaching' graduates are perhaps limiting themselves and it is quite difficult to imagine a similar programme for professions such as medicine, law or accountancy: 'Cure First' or 'Defend First' are not slogans we are likely to see in the near future. ${ }^{6}$

\footnotetext{
${ }^{6}$ A new two-year leadership programme for social work, 'Frontline', open to high-achieving graduates has been announced in June 2013 by the UK government, with first recruits planned to start the programme in 2014 (see www.thefrontline.org.uk).
} 


\section{Bibliography}

Adams, R. (2013) 'Number of new physics and maths teachers fail to meet official targets', The Guardian, Friday $6^{\text {th }}$ September 2013, http://www.theguardian.com/education/2013/sep/06/teacherapplications-physics-maths-education (accessed 18/09/13)

Ball. S.J., Maguire, M. and Macrae, S. (2000) Choice, Pathways and Transitions Post16. London: RoutledgeFalmer.

Ball, S.J. (2003) Class Strategies and the Education Market: The Middle Classes and Social Advantage, London: Routledge.

Ball, S.J. (2003) The teacher's soul and the terrors of performativity, Journal of Education Policy, Vol. 18 (2), pp.215-228.

Ball, S. (2013) The Education Debate (Second Edition), Bristol, Policy Press.

Bourdieu, P. (1977) Outline of a Theory of Practice, Cambridge: Cambridge University Press.

Bourdieu, P. (1997), 'The forms of capital' in A. H. Halsey, H. Lauder, P. Brown and A. Stuart Wells (eds), Culture, Economy, and Society, Oxford: Oxford University Press, 46-58.

Bradley, H. (1989) Men's Work, Women's Work, Cambridge: Polity Press.

Braun, A. (2009) Becoming Teachers: Gender, Biographies and a Borderland Profession, unpublished $\mathrm{PhD}$ thesis (Institute of Education, London).

Braun, A., Maguire, M. and Ball, S. (2010). Policy enactments in the UK secondary school: examining policy, practice and school positioning, Journal of Education Policy, Vol. 25 (4), pp.547560. 
Braun, A. (2012) Trainee teachers, gender and becoming the 'right' person for the job: care and authority in the vocational habitus of teaching, Oxford Review of Education, Vol. 38 (2) pp. 231246.

Braun, A., Vincent, C. \& Ball, S. (2011) Working class fathers and childcare: the economic and family contexts of fathering in the UK, Community, Work and Family, Vol.14 (1), pp.19-37.

Bottery, M. And Wright, N. (2000) Teachers and the State: Towards a Directed Profession, London: Routledge.

Britzman, D. (1991) Practice Makes Practice, New York: State University of New York Press.

Britzman, D. (2000) Teacher education in the confusion of our times, Journal of Teacher Education, Vol. 51 (3), pp. 200-205.

Clifford, G. (1987) '"Lady Teachers” and Politics in the United States, 1850-1930' in M. Lawn \& G. Grace (Eds.) Teachers: The Culture and Politics of Work. Lewes: Falmer Press.

Cockburn, A. and Haydn, T. (2004), Recruiting and Retaining Teachers: Understanding why Teachers Teach, London: Routledge.

Dale, A. and Egerton, M. (1997) Highly Educated Women: Evidence from the National Child Development Study, Research Studies RS25, Department for Educationa and Employment, London: The Stationary Office.

Devine, F. (2004) Class Practices: How Parents Help their Children Get Good Jobs, Cambridge: Cambridge University Press.

Devine, F. (2005) 'Middle-class identities in the United States' in Devine, F.; Savage, M.; Scott, J. and Crompton, R. (Eds) Rethinking Class: Culture, Identities and Lifestyle, Basingstoke: Palgrave, pp. $140-162$. 
Devine, F. (2008) Class, gender and occupational choices: occupational inheritance in medicine and teaching in the UK, seminar presented at IPSE, Metropolitan University, London, 08 October 2008.

Devine, F and Savage, M. (2005) 'The cultural turn, sociology and class analysis' in Devine, F.; Savage, M.; Scott, J. and Crompton, R. (Eds) Rethinking Class: Culture, Identities and Lifestyle, Basingstoke: Palgrave, pp. 1-23.

DfE (2010). "The Importance of Teaching: Schools White Paper 2010." available at https://www.education.gov.uk/publications/eOrderingDownload/CM-7980.pdf (accessed 27/08/13)

DfE (2013a) 'School Workforce in England: November 2012, released 30 April 2013’, https://www.gov.uk/government/uploads/system/uploads/attachment_data/file/223587/SFR15_2013 Text_withPTR.pdf (accessed 27/08/13)

DfE (2013b) New advice to help schools set performance- related pay, Press release Department for Education, 29 April 2013, https://www.gov.uk/government/news/new-advice-to-help-schools-setperformance-related-pay (accessed 18/09/13)

Dillabough, J-A. (1999) Gender politics and conceptions of the modern teacher: women, identity and professionalism, British Journal of Sociology of Education, Vol. 20 (3), pp. 373-394.

Etzioni, A. (1969) The Semi-Professions and their Organization: Teachers, Nurses, Social Workers, London: Collier-Macmillan.

Gilligan, C. (1982) In a Different Voice: Psychological Theory and Women's Development, Cambridge: Harvard University Press. 
Glick, J. and White, M. (2004) Post-secondary school participation of immigrant and native youth: the role of familial resources and educational expectations, Social Science Research, Vol. 33, pp. 272-299.

Gordon, J. (1994) Why students of color are not entering teaching: Reflections from minority teachers, Journal of Teacher Education, Vol. 45(5), pp.346-353.

Hargreaves, A. (2006) Four Ages of Professionalism and Professional Learning, in H. Lauder, P. Brown, J.-A. Dillabough and A.H. Halsey (Eds.) Education, Globalization and Social Change, Oxford: Oxford University Press, pp. 673-691.

Hargreaves, L., Cunningham, M., Hansen, A., McIntyre, D., Oliver, C. and Pell, T. (2007) The Status of Teachers and the Teaching Profession in England: Views from Inside and Outside the Profession, Research Report RR831A, London: Department for Education and Skills.

Hobson, A., Tracey, L., Kerr, A., Malderez, A., Pell, G., Simm, C. and Johnson, F. (2004), Why People Choose to Become Teachers and the Factors Influencing their Choice of Initial Teacher Training Route, Research Brief RBX08-04. London: Department of Education and Skills.

Hoyle, E. (2001) Teaching: Prestige, Status and Esteem, Educational Management \& Administration, Vol, 29(2), pp. 139-152

Johnston, J., McKeown, E. and McEwen, A. (1999) Choosing primary teaching as a career: the perspectives of males and females in training, Journal of Education for Teaching, Vol. 25 (1), pp. $55-64$.

Lawn, M. (1996) Modern Times? Work, Professionalism and Citizenship in Teaching, London: Falmer Press. 
Maddern, K. (2009) A class of their own? The rise and rise of the Teach First graduates, Times Educational Supplement, published 28 August 2009, http://www.tes.co.uk/article.aspx?storycode=6021552 (accessed 18/09/13)

Maddern, K. (2012) Teacher training gets overhaul, Times Educational Supplement, published 16 November 2012, http://newteachers.tes.co.uk/news/teacher-training-gets-overhaul/46478 (accessed $18 / 09 / 13)$

Maguire, M. (2001) 'The Cultural Formation of Teachers' Class Consciousness; Teachers in the Inner City', Journal of Education Policy, Vol. 16(4), pp.315-331.

Maguire, M. and Dillon, J. (2007) 'Reforming teachers and their work' in Dillon, J. and Maguire, M. (Eds.) Becoming a Teacher: Issues in Secondary Teaching, Maidenhead: Open University Press, pp.85-97.

Maylor, U. (2009) 'They do not relate to Black people like us': Black teachers as role models for Black pupils, Journal of Education Policy, Vol. 24(1), pp.1-21.

Menter, I. (2010) Teachers - Formation, Training and Identity: A Literature Review, Newcastleupon-Tyne: Creativity, Culture and Education Series.

Miller, J. (1992), More has Meant Women: the Feminisation of Schooling, London: The London File - Papers from the Institute of Education.

Morrison, A. (2012) Time for class: undergraduates' and lecturers' perceptions on why undergraduates want to teach, Sociological Research Online, Vol. 17 (3) 12.

Noddings, N. (2005) The Challenge to Care in Schools ( $2^{\text {nd }}$ Edition), New York: Teachers College Press. 
Observer (2013) 'I’d never held teachers in high regard - but now I do', Observer 20 July 2013, http://www.theguardian.com/education/2013/jul/20/teach-first-graduates (accessed 19/08/13)

ONS - Office for National Statistics (2010) Standard Occupational Classification 2010, Volume 1 and 2, London: Stationary Office. http://www.ons.gov.uk/ons/guide-method/classifications/current-

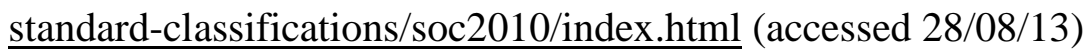

Oram, A. (1989) A master should not serve under a mistress: women and men teachers 1900-1970, in S. Acker (Ed) Teacher, Gender and Careers, Lewes: Falmer Press, pp. 21-34.

Paechter, C. (2007) Being Boys, Being Girls: Learning Masculinities and Femininities, Maidenhead: Open University Press.

Preston, J.A. (1995) Gender and the formation of a women's profession - the case of public school teaching, in J.A. Jacobs (Ed) Gender Inequality at Work, London: Sage, pp. 379-407.

Purcell, K. and Wilton, N. (2005) Education as a Graduate Career: Entry and Exit from Teaching as a Profession, Research Report 690, London: Department of Education and Skills.

Reay, D. (2001) Finding or losing yourself?: working class relationships to education, Journal of Education Policy, Vol.16 (4), pp.333-346.

Reay, D., Davis, M. and Ball, S. (2005) Degrees of Choice: Social Class, Race and Gender in Higher Education, Stoke on Trent: Trentham Books.

Reay, D. (2005) Beyond consciousness?: The psychic landscape of social class, Sociology, Vol. 39 (5), pp. 911-928.

Reid, I. and Thornton, M. (2000) Students' Reasons for Choosing Primary School Teaching as a Career, Hertfordshire: Centre for Equality Issues in Education, University of Hertfordshire. 
Sachs, J. (2001) Teacher professional identity: competing discourses, competing outcomes, Journal of Education Policy, Vol. 16 (2), pp.149-161.

Skelton, C. and Francis, B. (2009) Feminism and 'The Schooling Scandal', London: Routledge.

Smart, S. with Hutchings, M., Maylor, U., Mendick, H. and Menter, I. (2009) Processes of middleclass reproduction in a graduate employment scheme, Journal of Education and Work, Vol. 22(1), pp.35-53.

Stronach, I., Corbin, B., McNamara, O., Shark, S. and Warne, T. (2002) Towards an uncertain politics of professionalism: teacher and nurse identities in flux, Journal of Education Policy, Vol. 17 (1), pp.109-138.

Su, Z. (1997) Teaching as a profession and as a career: Minority candidates' perspectives, Teaching and Teacher Education, Vol. 13(3), pp.325-340.

TeachFirst (2013) http://www.teachfirst.org.uk/what-we-do (accessed 28/08/13)

Tomlinson, M. (2013) Education, Work and Identity, London: Bloomsbury.

Vincent, C. and Ball, S. J. (2006) Childcare, Choice and Class Practices: Middle-Class Parents and their Children, London: Routledge.

Wacquant, L. (1989) Towards a reflexive sociology: a workshop with Pierre Bourdieu, Sociological Theory, Vol. 7 (1), pp. 26-63.

Walkerdine, V., Lucey, H. and Melody, J. (2001) Growing up Girl: Psychosocial Explorations of Gender and Class, London: Macmillan 
Ward, S. and Eden, C. (2009) Key Issues in Education Policy, London: Sage.

Willis, R. (2005) The Struggle for the General Teaching Council, London: Routledge.

Wright, A. (2012) Fantasies of empowerment: mapping neoliberal discourses in the coalition government's school policy, Journal of Education Policy, Vol. 27 (3), pp. 279-294. 
Table 1. NS-SEC occupational classification of family (highest class whether mother or father)

\begin{tabular}{|c|c|}
\hline NS-SEC occupation & Family $(n=32)$ \\
\hline Class 1.1 higher managerial & 0 \\
\hline Class 1.2 higher professional & 9 \\
\hline Class 2 lower managerial and professional & 11 \\
\hline Class 3 intermediate & 5 \\
\hline $\begin{array}{l}\text { Class } 4 \text { own account worker (e.g. small } \\
\text { business owners) }\end{array}$ & 3 \\
\hline Class 5 lower supervisory and technical & 2 \\
\hline Class 6 semi-routine & 1 \\
\hline Class 7 routine & 1 \\
\hline Class 8 never-worked, long-term unemployed & 0 \\
\hline Unclassified & 0 \\
\hline
\end{tabular}

